\title{
STUDY OF OUTWARD SIGNS, MICROSCOPY AND CHEMICAL COMPOSITION OF WALNUT
}

\author{
STRELYAEVA AV ${ }^{1}$, LEZHAVA DI ${ }^{1}$, LUFEROV AN ${ }^{1}$, BOBKOVA NV ${ }^{1}$, KARTASHOVA NV $^{1}$, KUZNETSOV RM $^{2}$
}

${ }^{1}$ Department of Pharmaceutical and Natural Sciences, Sechenov First Moscow State Medical University, Moscow 119991, Russia. ${ }^{2}$ Department of Pharmaceutical Science, Laboratory of Pharmacokinetics and Metabolism Analysis, Sechenov First Moscow State Medical University, Moscow 119991, Russia. Email: nataliekartashova@gmail.com

Received: 29 June 2018, Revised and Accepted: 06 September 2018

\section{ABSTRACT}

Objective: Walnut is a medicinal plant that is widely used in traditional medicine. We believe that the study of the medicinal plant material of walnutfruit in the stage of milky-wax maturity and walnut bark is relevant. We described outward signs and microscopy, the diagnostic features of both whole and grinded raw materials, powder bark of walnut and fruits of walnut in the stage of milky-wax maturity.

Methods: Alcohol extraction which was derived from walnut bark is a transparent liquid of brown color and alcohol extraction which was derived walnut fruits in the stage of milky-waxy maturity is a transparent, green-brown liquid with a fragrant smell. We performed thin-layer chromatography for the walnut cortex and identified gallic acid.

Results: A method of chromatography-mass spectrometry in alcohol extraction from walnut fruit in the stage of milky-waxy maturity allowed to identify 17 compounds belonging to different classes of biologically active substances. We identified sugars, flavonoids, phenolic compounds of coumarins and organic acids. In alcohol extraction from the walnut bark we identified marker substances.

Keywords: Walnut, Walnut bark, Walnut fruit.

(c) 2019 The Authors. Published by Innovare Academic Sciences Pvt Ltd. This is an open access article under the CC BY license (http://creativecommons. org/licenses/by/4. 0/) DOI: http://dx.doi.org/10.22159/ajpcr.2019.v12i1.28197

\section{INTRODUCTION}

At present, an impressive number of scientists around the world is engaged in the search for new natural biologically active substances; thorough study of the pharmacological action of known BAS, i.e., actions on individual systems and the body as a whole; is engaged in the search for new sources of biologically active substances, more economically advantageous. These sources are plants. Scientists have given nature the widest choice of objects for research. One of them is a powerful plant with a majestic crown - a walnut (Juglans regia L.), one of the popular names of which is the royal nut $[1,2]$.

Many researchers mentioned this medicinal plant in their literary works, having previously conducted many experiments to study the chemical composition - these are qualitative reactions to the main groups of BAS, the paper chromatography method, and the thinlayer chromatography (TLC) method. Quantitative determination of ultraviolet (UV) spectrophotometry and high-performance liquid chromatography [3-6] was carried out.

Qualitative reactions determined the rich chemical composition. In the medicinal plant, there are quinones (naphthoquinone juglone and $\alpha$ and $\beta$-hydrogens), flavonoids (hyperoside and kaempferol), Vitamin B, ascorbic acid, tannins, carotenoids, phenolic acids, lilac aldehyde, and juglone and this is only in the leaves [4,7-10].

Green pericarp contains hydrocoals and tannins. In the kernels of walnut fruit identified fatty oils, protein substances, Vitamins $\mathrm{K}$ and $\mathrm{P}$, and amino acids [11-13]. The raw material of walnut is widely used in folk medicine and homeopathy [7,14]. A number of researchers indicate a wide pharmacological activity of various types of walnut raw materials. Hence, according to a number of authors [7,14], walnut has a pronounced antitumor effect and antiproliferative activity [15]. The extract from walnut fruit shows high antifungal, antimicrobial, and antioxidant activity [16-19,20]. The antifungal action of the ethanol extract from the roots of walnut has been revealed. Petroleum extraction from walnut fruit showed high anthelmintic activity and antiparasitic action [21,22].

The aim of the study is to study external features, microscopy of walnut bark raw materials and walnut fruit in the stage of milky-wax maturity and chemical composition of alcohol extraction from these types of raw materials.

\section{METHODS}

The object of the study was the medicinal plant raw materials of walnut fruit in the stage of milky-wax maturity and the walnut bark, as well as alcohol extraction from this type of raw material. The material of the study was samples of the bark and fruit of walnut (J. regia L.), collected in the Moscow region, air-shade dried, and used as medicinal plant material.

Fruits were harvested in June in the stage of milky-wax maturity.

To perform the cuts, the dried bark was soaked in a mixture of $95 \%$ ethanol-glycerol-water (1:1:1). Cross-sections were examined using a light microscope.

Photographs were performed using a Canon Digital IXUS 80 IS digital camera. Alcohol extraction was prepared using $96 \%$ alcohol by the method of obtaining a tincture of the matrix homeopathic [23]

The component composition of the samples was studied by gas chromatography-mass spectrometry. The study was carried out on an Agilent Technologies instrument consisting of (1) 7890 gas chromatograph (HP-5 column, $50 \mathrm{~m} \times 320 \mu \mathrm{m} \times 1.05 \mu \mathrm{m}$ ) and 2) 5975 C mass-selective detector with quadrupole mass analyzer. Temperature program of chromatography: $40^{\circ} \mathrm{C}$, isotherm for 2 mins, further programmed heating to $250^{\circ} \mathrm{C}$ at a rate of $5^{\circ} \mathrm{C} / \mathrm{min} ; 250^{\circ} \mathrm{C}$ - 
isotherm for $15 \mathrm{~min}$; further programmed heating to $320^{\circ} \mathrm{C}$ at a speed of $25^{\circ} \mathrm{C} / \mathrm{min}$; at $320^{\circ} \mathrm{C}$ - isotherm for $5 \mathrm{~min}$. Injector with flow division 1:50. Injector temperature is $250^{\circ} \mathrm{C}$. The interface temperature is $280^{\circ} \mathrm{C}$. The carrier gas is helium; flow rate $1 \mathrm{ml} / \mathrm{min}$. The chromatogram of the samples is based on the total ion current. Mass spectrometric analysis conditions: Ionizing electron energy $70 \mathrm{eV}$; registration of mass spectra in positive ions in the range $(\mathrm{m} / \mathrm{z})$ from 20 to 450 at a rate of $2.5 \mathrm{scan} / \mathrm{s}$. Software - ChemStation E 02.00. Identification of the component composition (qualitative analysis) was carried out from the NIST-05 complete mass spectra library and the corresponding values of chromatographic linear retention indices. The relative content (\%) of the components of the mixture (quantitative analysis) was calculated from the ratio of the areas of chromatographic peaks (by the simple normalization method) [24].

External signs of solid raw materials were investigated. The cortex is examined with the naked eye or with a magnifying glass $(\times 10)$ or a stereomicroscope $(\times 8, \times 16)$ in accordance with the section "methods of analysis of medicinal raw materials" [25]

\section{RESULTS AND DISCUSSION}

Fresh raw materials are trough-shaped pieces of bark, 5-6 cm long, about 2-3 mm thick. The external surface of the cortex is smooth with transverse wrinkles (Fig. 1). There are lenticels of round shape. The inner surface of the bark is smooth. In the fracture, the edge is fibrous. The color of the bark from the outside is brown and grayishbrown, inside is yellowish flesh. The smell is weak when the cortex is moistened with water it does not increase. The taste is bitterish.

Dried raw materials are trough-shaped pieces of bark, some are curled, a length of 5-6 cm, a thickness of about 2-3 mm. The external surface of the cortex is smooth with transverse wrinkles (Fig. 1). There are lenticels of round shape. The inner surface of the bark is smooth. In the fracture, the edge is fibrous. The color of the bark outside is brown and grayish-brown, inside yellowish fleshy, light brown. The smell is weak when the cortex is moistened with water it does not increase. The taste is bitterish.

External signs of crushed raw materials were researched. Pieces of bark of various shapes, mostly rectangular. They pass through a sieve with apertures $7 \mathrm{~mm}$ in diameter. The color of the raw material is from light brown to dark reddish-brown. A dark gray-brown color is possible (Fig. 2). The smell is weak, increasing with soaking. The taste is bitter.

\section{Powder}

The powder has grayish brown color, passing through a sieve with holes $0.5 \mathrm{~mm}$ in diameter (Fig. 4). The smell is weak, peculiar. The taste is bitter.

The periderm of the bark collected from 2 to 5 -year-old branches is represented mainly by a multilayered fallen (cork) consisting of 4-6 layers of thin-walled, cross-sectioned tabular cells colored in brown. The outer layers of the plug consist of colorless, dead, scaly, sloughing cells. Phelloderm cells located under the pigmented layer of the plug are not colored, compressed, and deformed (Fig. 3a and b)

Under the periderms are 3-4 layers of collenchyma cells, slightly transversely tangentially elongated, with thickened walls and greenishamorphous contents (Fig. 3b).

Parenchyma of the primary cortex consists of isodiametric polygonal or oval cells, the walls of which are often permeated with pores. Some parenchyma cells contain druzes of calcium oxalate, greenish amorphous contents, and starch. Sometimes, intercellular cavities are observed in the parenchyma of the primary cortex (Fig. 3b).

The inner zone of the primary cortex is characterized by the presence of a discontinuous "mechanical belt" consisting of groups of stone cells (sclereids) and mechanical fibers, forming a primary cortex (Fig. 3a).

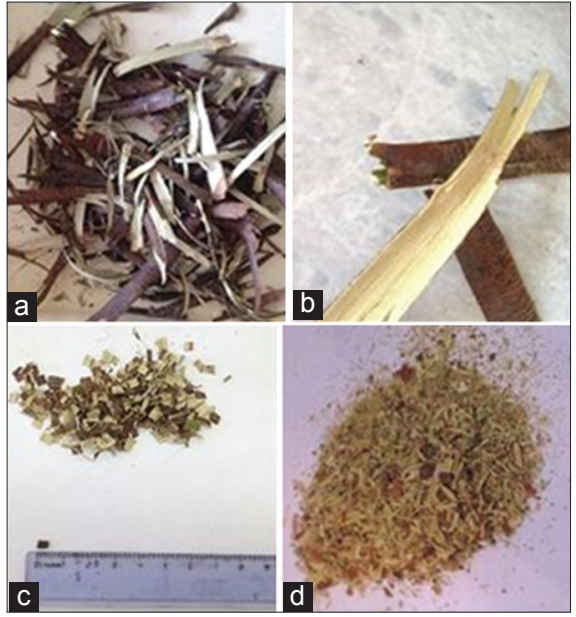

Fig. 1: (a-d) Fresh and dried whole raw materials, dried shredded raw materials, walnut bark powder

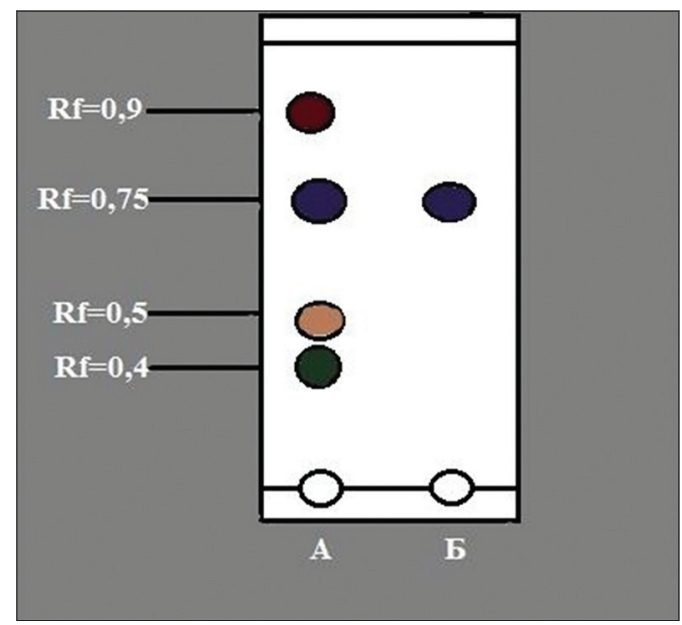

Fig. 2: Chromatogram of alcohol extract from the walnut bark for the detection of gallic acid

Fibers are narrow, with a diameter of $12-25 \mu$, with very thick walls, permeated with a few simple pores, with a point (sometimes silicate) cavity. Larger in diameter fibers can be found in small groups of 1-3, fiber size in the bundles is somewhat smaller. Different sclereids of $60-90 \mu \mathrm{m}$ in size have strongly thickened layered walls with numerous porous tubules (Fig. 3a and c).

The fiber bundles of the "mechanical belt" are powerful, rounded in outline, with them complex groups of stony cells oriented tangentially or radially, which is consistent with the data of other authors [26]. These elements of the stereotype alternate with the areas of the cells of the cortical parenchyma (Fig. 3c). In the bark of the older branches, the stereo is formed as a solid ring.

In the secondary cortex, a typical sequence of alternating layers of soft bast and bundles of mechanical fibers forming a stereo (solid bast) is observed in the form of several tangentially oriented layers, which are penetrated by primary and secondary core rays (Fig. 3a), secondary rays - single-row, small-celled. Cells of primary rays are larger, have porous walls and form multirow radially oriented areas (Fig. 3a and e).

Some cells of the soft bast contain druzes of calcium oxalate, with a diameter of 8-27 $\mu$. On the longitudinal-radial sections, whole strands of the crystal-bearing parenchyma accompanying the bundles of mechanical fibers are visible (Fig. 3d). 


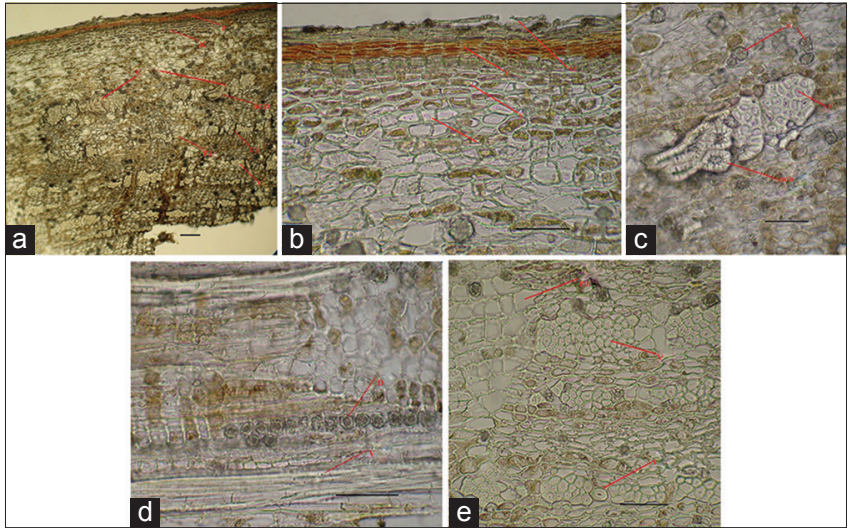

Fig. 3: (a) Is the transverse section of the cortex (scale of $100 \mu \mathrm{m}$ ) c - mechanical fibers; v.l. - secondary beam; plural - cells of the primary ray; with - the stereo of the primary crust ("mechanical

belt"); $\mathbf{k}$ - collenchyma; $p$ is the periderm; scd - scleraide.

(b) Fragment of transverse cut of the cortex, peridermal zone, collenchyma, and primary cortex (scale ruler $50 \mu \mathrm{m}$ ) f - the femme; nf - outer layers of the fellemy; $k$ - collenchyma. (c) A fragment of the transverse cut of the cortex, the zone of the primary cortex, the section of the "mechanical belt" (scale ruler $50 \mu \mathrm{m}$ ); $\mathrm{v}$ - mechanical fibers; $d$ - druza of calcium oxalate; scd - sclereide. (d) A fragment of the longitudinal-radial cut of the cortex, the zone of the secondary crust (scale ruler $50 \mu \mathrm{m}$ ) c - mechanical fibers; $d$ - druza calcium oxalate. (e) A fragment of the transverse cut of the cortex, the zone of the secondary crust (scale ruler $50 \mu \mathrm{m}$ ) c - mechanical fibers; p.l. - cells of the primary ray

Thus, to standardize the medicinal plant material - the walnut bark, diagnostic anatomical signs were established. These include the features of the structure of periderm, the stereomy of the primary and secondary cortex, the presence of crystalline inclusions (drusen of calcium oxalate).

When wetting the inner surface of the bark with a drop of $1 \%$ ferric ammonium alum solution, a greenish-black color is observed (Fig. 4).

\section{Qualitative reactions}

The ground bark in the amount of $0.1 \mathrm{~g}$ is boiled for 2-3 min with $10 \mathrm{ml}$ of water, cooled and filtered. To $1 \mathrm{ml}$ of the filtrate, 2-3 drops of a $1 \%$ solution of iron ammonium alum are added: A black color is observed.

On the bark, 2-3 drops of 5\% sodium hydroxide solution are applied: A violet-brown color is observed.

The powder is placed on a slide and 2-3 drops of a 1\% solution of iron ammonium alum are dripped: A blue color is observed, which turns into black (hydrolyzed tannins) (Fig. 4)

The powder is placed on a slide and 2-3 drops of a 5\% solution of sodium hydroxide drop: Yellow color is observed, which turns into red (phenolic compounds and anthraquinone derivatives) (Fig. 4).

\section{TLC - analysis of alcohol extraction of the walnut bark}

To the start line of the finished chromatographic plate with a layer of "Sorbphil" silica gel, $20 \mu \mathrm{l}(0.02 \mathrm{ml})$ of the test tincture and $5 \mu \mathrm{l}(0.005 \mathrm{ml})$ of $0.1 \%$ solution of gallic acid POO are applied separately and strip chromatographed in an ascending system in a solvent system chloroform:acetic acid ice:ethanol:water (15:8:3:2) to a height of $10 \mathrm{~cm}$. The plate is then removed from the chamber, dried in air to remove traces of solvents, and examined in UV light at a wavelength of $365 \mathrm{~nm}$.

In UV light at a wavelength of $365 \mathrm{~nm}$, a brown zone with a Rf of about 0.75 should be detected on a chromatogram of $0.1 \%$ solution of gallic acid.

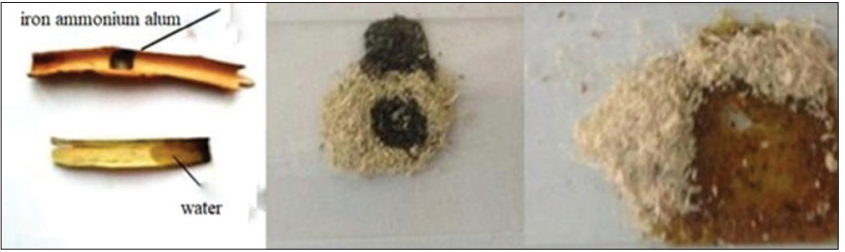

Fig. 4: Results of histochemical reaction of whole walnut crust and walnut crust powder with $1 \%$ ferric ammonium alum solution and the result of reaction of walnut crust powder with $5 \% \mathrm{NaOH}$

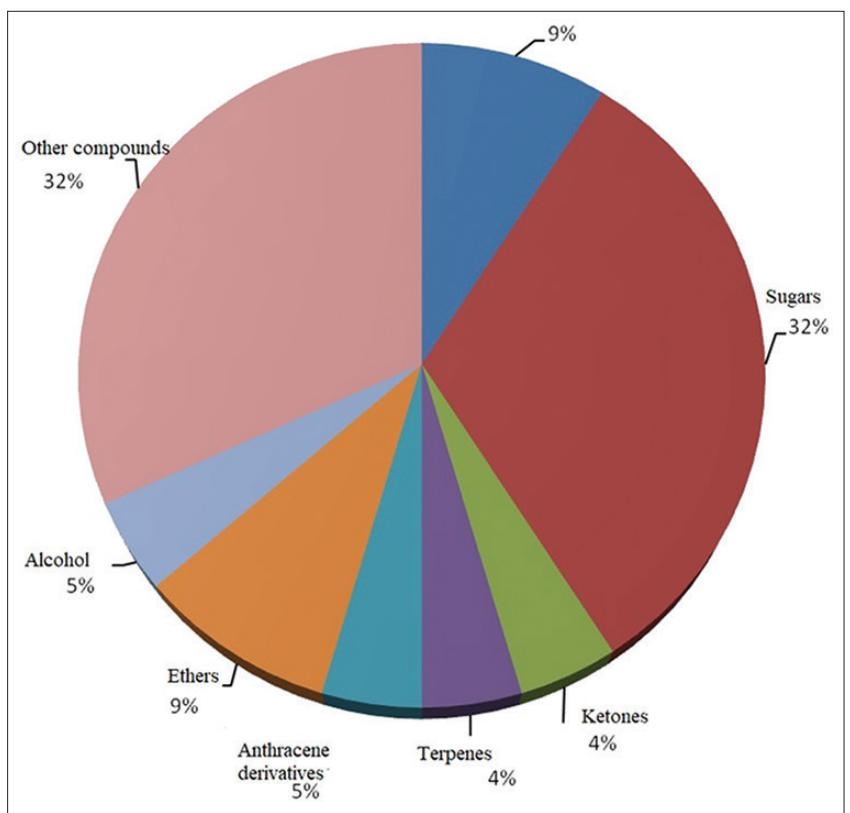

Diagram 1: The relative content of active substances in alcohol extraction from the bark of a walnut

In UV light at a wavelength of $365 \mathrm{~nm}$ on the chromatogram, brown zones with Rf about 0.5 and 0.9; in addition, zones can be found: Brown with Rf about 0.4.

In the extraction from the bark of the walnut by TLC, tannic substances, gallic acid, were found (Table 1).

The relative percentage of each component was calculated taking into account unidentified peaks (Fig. 1).

The maximum content falls on sugar, namely for sucrose $25.27 \%$, for ethyl- $\alpha$-D-glucopyranosyl $29.75 \%$, and for lactose $4.86 \%$.

Terpenic compounds have been identified, the total content of which is almost the secondplace. The content of camphor is $9.63 \%$, the content of cineol is $0.9 \%$, and the content of thujone is $0.4 \%$ (Diagram 1 ). The marker compounds are the derivatives of yuglon 4,5-dihydroxy3,4-dihydro-1(2H)-naphthalenone and anthracene derivative 4, 5-dihydroxy-3,4-dihydro-1 (2H)-naphthalenone. With these compounds, the pharmacological activity of medicinal plant material is associated.

The research task included the study of raw walnut fruit in the stage of milky-wax maturity. Microscopy of the fetus was prepared according to the generally accepted procedure $[27,28]$. It should be noted the most important diagnostic signs of the fruit: The epidermal cells of the "final" structure; grouped large oval stomata of anomocytous type; hairs simple, unicellular, thick-walled, joined at 2-4 in the base rarely; hairs head with a 1-3- or multicellular single-rowed pedicle and a multicellular glandular head (rarely) and rounded-colored places of attachment of simple and glandular hairs [27-30]. 
Table 1: Substances contained in alcohol extraction of the walnut bark

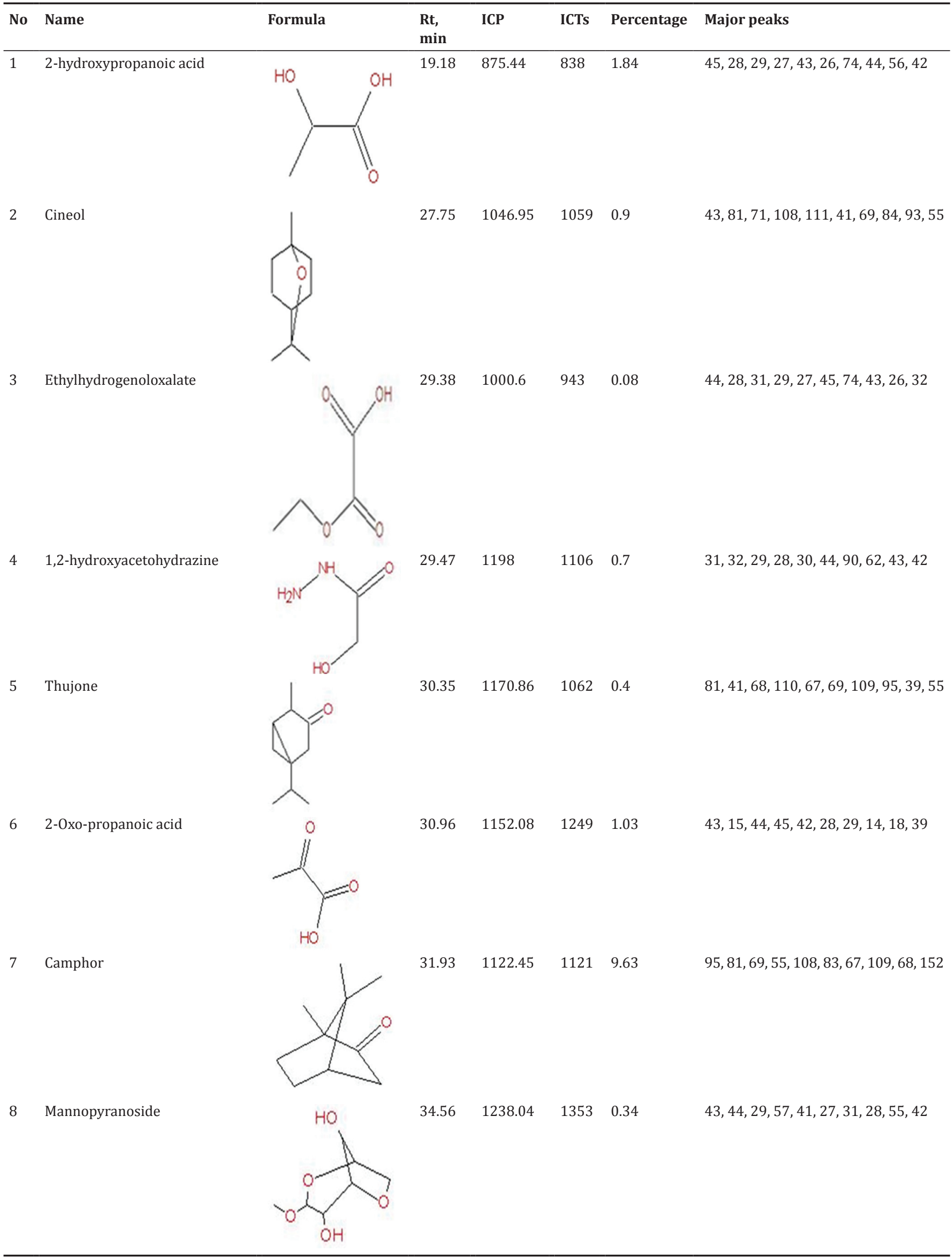


Table 1: Continued

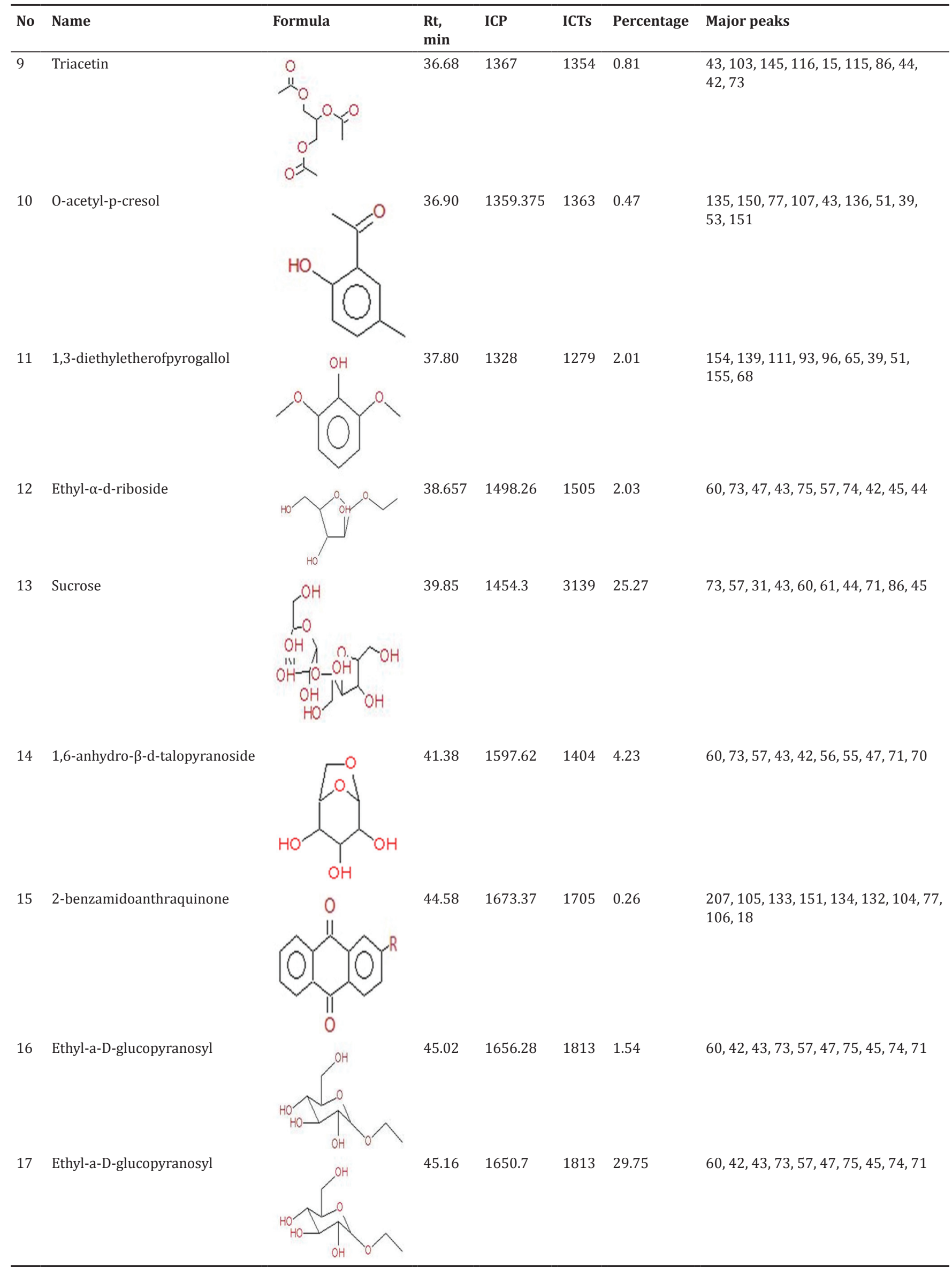


Table 1: Continued

\begin{tabular}{|c|c|c|c|c|c|c|c|}
\hline No & Name & Formula & $\begin{array}{l}\text { Rt, } \\
\text { min }\end{array}$ & ICP & ICTs & Percentage & Major peaks \\
\hline 18 & Lactose & & 45.67 & 3116 & 3131 & 4.86 & $73,43,60,31,61,57,85,71,29,103$ \\
\hline 19 & $\begin{array}{l}\text { 4,5-dihydroxy-3,4-dihydro-1 } \\
(2 \mathrm{H}) \text {-naphthalenone }\end{array}$ & & 47.14 & 1776.61 & 1746 & 3.71 & $88,101,55,41,89,43,27,57,73,70$ \\
\hline 20 & Ethyl palmitate & & 56.42 & 1907.586 & 1978 & 4.61 & $\begin{array}{l}160,131,132,121,39,104,77,66, \\
64,103\end{array}$ \\
\hline
\end{tabular}

We examined the transverse section of the pericarp. An exocarpus consists of a single-layered small-celled epidermis covered with a layer of yellowish cuticle. A four-layer collenchyma underlies the epidermis. We found a mechanical belt consisting of thick-walled stony cells of various shapes pierced with pores. We also investigated mesocarp, consisting of large thin-walled parenchymal cells with greenish granular contents, druzes of calcium oxalate, randomly scattered conductive bundles with spiral vessels and tracheids and stony cells with porous layered, not very thick walls. We examined endocarp which consists of sclerized porous cells, and parenchymal cells. When examining the micropreparation of the seed coat from the surface, we found polygonal brownish cells of the epidermis; very large stomata with a gaping stomatal gap and kidney-shaped terminal cells; under the epidermis. In the study of the micropreparation of the transverse section of the cotyledons (seed embryo), thin-walled parenchymal cells with granular contents are visible; drops of fatty oil in the immature nucleus are rare $[27,28]$.

Alcohol extraction, obtained from medicinal plant raw materials of walnut fruits in the stage of milky-wax maturity, is a transparent, green-brown liquid with a fragrant smell. Using the chromatography-mass spectrometry method for alcohol extraction from walnut fruit, 17 compounds were identified in the milk-wax stage, related to different classes of BAS.

Sugars, flavonoids, phenolic compounds and coumarins, juglone, and organic acids were identified.

\section{CONCLUSION}

1. In describing external signs and microscopy, diagnostic features of both whole and shredded raw materials and powder of the walnut crust, as well as its fruit in the stage of milky-wax maturity, were revealed.

2. Alcohol extraction derived from medicinal plant raw materials, walnut bark is a transparent liquid of brown color. Alcohol extraction, obtained from the medicinal plant raw material of walnut fruits in the stage of milky-waxy maturity, is a transparent, green-brown liquid with a fragrant smell. TLC in the walnut cortex identified gallic acid.

3. The method of chromatography-mass spectrometry in alcohol extraction from walnut fruit in the stage of milk-wax maturity was able to identify 17 compounds belonging to different classes of BAS. Sugars, flavonoids, phenolic compounds of coumarins, and organic acids were identified. Alcohol extraction from the walnut bark identified marker compounds, the combination of which makes it possible to quickly identify this type of feedstock by chromatographymass spectrometry marker compounds derivatives of yuglon 4,5-dihydroxy -3,4-dihydro-1 (2H)-naphthalenone and derivative anthracene 4,5-dihydroxy-3,4-dihydro-1 (2H)-naphthalenone. With these compounds, the pharmacological activity of medicinal plant material is associated.

\section{ACKNOWLEDGMENTS}

The authors would like to grateful to the Department of Pharmaceutical and Natural Sciences of Sechenov First Moscow State Medical University, Moscow, for providing infrastructure and instrumentation facilities.

\section{AUTHORS' CONTRIBUTION}

A.N. Luferov, N.V. Bobkova, and A.V. Strelyaeva conceived of the presented idea. A.V. Strelyaeva developed the theory and performed the computations. N.V. Kartashova and R.M. Kuznetsov verified the analytical methods. All authors discussed the results and contributed to the final manuscript. D.I. Lezhava, N.V. Kartashova, and R.M. Kuznetsov carried out the experiment. D.I.Lezhava wrote the manuscript with support from N.V. Kartashova.

\section{CONFLICTS OF INTEREST}

We have no conflicts of interest to declare.

\section{REFERENCES}

1. Andrienko MV, Zatokovsky FT. Walnut in Transdniestria. Russia: Gardening and Viticulture; 1989. p. 10-2.

2. Chikov PS. Atlas of Areals and Resources of Medicinal Plants of the USSR. Moscow: GUGKL; 1980. p. 247.

3. Solar A, Colaric M, Usenik V, Stampar F. Seasonal variations of selected flavonoids, phenolic acids and quinones in annual shoots of common walnut (Juglans regia L.) Plant Sci 2006;170:453-61.

4. Labuckas DO, Maestri DM, Perello M', Martinez ML, Lamarque AL. Phenolics from walnut (Juglans regia L.) kernels: Antioxidant activity and interactions with proteins Food Chem 2008;107:607-12.

5. Dyironas ZV, Pshukova IV. Study of the composition of the lipophilic 
fraction of walnut leaves growing in the Caucasian mineral waters. Chem Plant Raw Mater 2010;4:91.

6. Abdallah IB, Tlili N, Martinez-Force E, Rubio AG, Perez-Camino MC, Albouchi A, et al. Content of carotenoids, tocopherols, sterols, triterpenic and aliphatic alcohols, and volatile compounds in six walnuts (Juglans regia L.) varieties. Food Chem 2015;173:972-8.

7. Enikeeva RA. Walnut Walnut Juglans regia L. and Its Application in Medical, Including Homeopathic Practice. SAT Scientific Works Russian Homeopathic Congress; 2007. p. 216-7.

8. Enikeeva RA, Sokolskaya TA, Dergayeva TD. Characterization of Microdiagnostic Features of Walnut. Pyatigorsk: Sborn Scientific Works Development, Research and Marketing of New Pharmaceutical Products; 2005 p. 44-6.

9. Enikeeva RA. A Study on the Pharmacological Study and Standardization of Raw Materials and Preparations of Walnut Walnut. The Dissertation Author's Abstract on Competition of a Scientific Degree of the Candidate of Pharmaceutical Sciences; 2008.

10. Colaric M, Veberic R, Solar A, Hudina M, Stampar F. Phenolic acids, syringaldehyde, and juglone in fruits of different cultivars of Juglans regia L. J Agric Food Chem 2005;53:6390-6.

11. Dev TM, Apraj V, Bhagwat A, Mallya R, Sawant L, Pandita N. Pharmacognostic and phytochemical investigation of Juglans regia Linn. Bark Pharm J 2011;21:39-43.

12. Fukuda T, Ito H, Yoshida T. Antioxidative polyphenols from walnuts (Juglans regia L.) Phytochemistry 2003;63:795-801.

13. Wianowska D, Garbaczewska S, Cieniecka-Roslonkiewicz A, Dawidowicz AL, Jankowska A. Comparison of antifungal activity of extracts from different Juglans regia cultivars and juglone. Microb Pathog 2016;100:263-7.

14. Enikeeva RA, Dergayeva TD, Sokolskaya TA. Development of Methods for Assessing the Quality of the Tincture of the Matrix Homoeopathic "YUGLON". Materials of the Regional Scientific and Practical Conference with International Participation, Dedicated To the $40^{\text {th }}$ Anniversary of the Pharmaceutical Faculty of KSMU "Achievements, Perspectives of Pharmaceutical Science and Practice". Kursk; 2006. p. 285-8.

15. Carvalho M, Ferreira PJ, Mendes VS, Silva R, Pereira JA, Jerónimo C, et al. Silva human cancer cell antiproliferative and antioxidant activities of Juglans regia L. Food Chem Toxicol 2010;48:441-7.

16. Fernández-Agulló A, Pereira E, Freire MS, Valentão P, Andrade PB, González-Álvarez J, et al. Influence of solvent on the antioxidant and antimicrobial properties of walnut (Juglans regia L.) green husk extracts. Ind Crops Prod 2013;42:126-32.

17. Oliveira I, Sousa A, Ferreira IC, Bento A, Estevinho L, Pereira JA. Total phenols, antioxidant potential and antimicrobial activity of walnut (Juglans regia L.) green husks Food Chem Toxicol 2008;46:2326-31.

18. Pereira JA, Oliveira I, Sousa A, Ferreira IC, Bento A, Estevinho L.
Bioactive properties and chemical composition of six walnut (Juglans regia L.) cultivars. Food Chem Toxicol 2008;46:2103-11.

19. Pereira JA, Oliveira I, Sousa A, Valenta o P, Andrade PB, Ferreira OC, et al. Walnut (Juglans regia L.) leaves: Phenolic compounds, antibacterial activity and antioxidant potential of different cultivars. Food Chem Toxicol 2007;45:2287-95.

20. Raja V, Ahmad SI, Irshad M, Wani WA, Siddiqi WA, Shreaz S, et al. Anticandidal activity of ethanolic root extract of Juglans regia (L.): Effect on growth, cell morphology, and key virulence factors. J Mycol Med 2017;27:476-86.

21. Gorlov IF, Yurina IS. Application for a Patent for an Image: A Method for Obtaining an Extract of Walnuts of Milky Wax Ripeness in Aviation Kerosene. Pat Russia 2011.

22. Strelyaeva AV. Study of toxicity and pharmacological activity of preparations based on medicinal plant raw materials and new extractants. Dis Doct Farm Sci M 2003;32:325.

23. Samylina IA, Strelyaeva AV, Lazareva NB, Sadykov VM. Homeopathic Preparations from Pharmacopeial Medicinal Plant Raw Materials: Textbook. New York: Medical Information Agency; 2012. p. 432

24. Shcheglova TA, Kurilov DV, Strelyaeva AV. The chemical composition and antioxidant activity of mother tincture from the leaves of Salvia officinalis. Pharmacy 2012;3:34.

25. Russian State Pharmacopoeia 13. [El, Resource]. Available from: http:// www.pharmacopoeia.ru/gosudarstvennaya-farmakopeya-xiii-onlinegf. [Last accessed on 2018].

26. Dayronas ZV. Morphological and anatomical study of walnut walnut (Juglans regia L.), gray walnut (Juglans cinerea L.) and walnut black (Juglans nigra L.). Mod Probl Sci Educat 2015; 2015:1-2.

27. Bobkova NV. Microscopic examination of immature walnut fruit. In: Ermakova VA, Bobkova NV, Samylina IA, editors. Traditional Medicine - 2007 Collection of Scientific Papers of the Congress. Moscow M: Publishing House of the Federal Scientific Clinical Experimental Center of Traditional Methods of Diagnostics and Treatment of Roszdrav; 2007. p. 43-7.

28. Samylina IA, Ermakova VA, Bobkova NV, Anosova OG. Pharmacognosy Atlas. T. 3 Medicinal Plant Raw Materials, Collections. Vegetable powders. Medicines Based On Crushed Raw Materials. New York: GEOTAR - Media; 2013. p. 52-6.

29. Noor S Jaafar, Maha N Hamad, Ibrahim S Abbas, Iman S Jaafar. Qualitative phytochemical comparsion between flavonoids and phenolic acids contents of leaves and fruits of Melia azedarach (Family: meliaceae) cultivated in iraq by HPLC and HPTLC. Int J Pharm Pharm (IJPPS) Sci 2016;8(10):242-250.

30. Muchtaridi M, Suryani D, Qosim WA, Saptarini NM. Quantitative analysis of $\alpha$-mangostin inmangosteen (Garcinia mangostana L.) pericarp extracts fromfour districts of west java by HPLC method. Int J Pharm Pharm (IJPPS) Sci 2016;8:232-6. 